\title{
The Inhibitory Effect of Heme on Heme Formation In Vivo: Possible Mechanism for the Regulation of Hemoglobin Synthesis *
}

\author{
ROBERT C. Gallo $\dagger$ \\ (From the Medicine Branch, National Cancer Institute, National Institutes of Health, \\ Bethesda, Md., and the Department of Medicine, University of Chicago, \\ Chicago, Ill.)
}

Summary. 1) The effect of hemin on heme synthesis was studied in vivo. Heme synthesis was measured by determining red cell ${ }^{50} \mathrm{Fe}$ uptake and glycine-2- ${ }^{14} \mathrm{C}$ incorporation into red cell hemin in normal $\mathrm{CF}_{1}$ female mice.

2) Both bovine and human hemin significantly decreased red cell ${ }^{59} \mathrm{Fe}$ uptake 48, 72, and 96 hours after hemin injection.

3) Glycine-2- ${ }^{14} \mathrm{C}$ incorporation into red cell hemin was decreased to $50 \%$ of control values after the administration of hemin ( $90 \mu$ moles per $\mathrm{kg}$ ).

4) There was no significant difference between the plasma iron of mice injected with hemin and the values in control groups.

5) Protoporphyrin decreased the inhibitory effect of hemin on red cell ${ }^{59} \mathrm{Fe}$ uptake by $64 \%$.

6) There was no measurable effect of $\delta$-aminolevulinic acid on hemin inhibition of red cell ${ }^{59} \mathrm{Fe}$ uptake.

7) Data are presented to show that the effect of hemin is not by a dilution mechanism nor by a decrease in red cell maturation and subsequent release of reticulocytes into the peripheral blood. The findings are discussed in regard to the possible site of a negative feedback control of heme synthesis by heme.

\section{Introduction}

Recent evidence from in vitro studies suggests that an end product feedback control process may be important in the regulation of heme biosynthesis. $\delta$-Aminolevulinic acid synthetase (ALAS) is the first and rate-limiting enzyme in the heme biosynthetic pathway (1), and Burnham and Lascelles have shown an inhibitory effect of hemin on this enzyme in the microorganism Rhodopseudomonas spheroides (2). Heady, Jacobs, and Deibel have demonstrated that the addition of hemin to cultures of Staphylococcus epidermidis inhibits the accumulation of coproporphyrin un-

\footnotetext{
* Submitted for publication May 18, 1966; accepted September 28, 1966.

A partial report of this work was presented at the meeting of the American Society of Hematology, December 7, 1965.

† Address requests for reprints to Dr. Robert C. Gallo, National Cancer Institute, Bethesda, Md. 20014.
}

der conditions of impaired heme synthesis (3). Recently Karibian and London have demonstrated an inhibitory effect of hemin on the utilization of glycine-2-14 $\mathrm{C}$ for heme synthesis in rabbit reticulocytes (4). The data from these in vitro experiments suggest that heme synthesis is at least in part regulated by a feedback control mechanism. An in vivo study of the effects of heme would clarify the physiologic significance of their results. The results presented in this communication indicate that heme inhibits heme synthesis in vivo.

\section{Methods}

Heme synthesis was measured in normal $\mathrm{CF}_{1}$ female mice (weight, 20 to $27 \mathrm{~g}$ ) by determining the incorporation of glycine-2- ${ }^{14} \mathrm{C}$ (SA, $21.9 \mathrm{mc}$ per mmole) ${ }^{1}$ into hemin crystallized from erythrocytes of the peripheral

1 New England Nuclear Corp., Boston, Mass., lot no. 148-211A-65. 
blood and by measuring red cell uptake of ${ }^{50} \mathrm{Fe}^{2}$ (SA, $1.1 \mathrm{mc}$ per $\mathrm{mg}$ ).

Preparation of solutions. Heme was obtained commercially as the bovine hemin chloride ${ }^{3}$ or prepared directly from human blood by the method of Labbe and Nishida (5). One $\mathrm{mg}$ of hemin was dissolved in $0.05 \mathrm{ml}$ $1 \mathrm{~N} \mathrm{NaOH}$ and $1.0 \mathrm{ml}$ distilled $\mathrm{H}_{2} \mathrm{O}$ and buffered with $0.05 \mathrm{ml} 1 \mathrm{M}$ Tris ( $\mathrm{pH} 8.2)$; the $\mathrm{pH}$ of the alkaline hematin solution was adjusted to 7.5 with $1 \mathrm{~N} \mathrm{HCl}$ (6). Control (solvent) solutions were similarly prepared except for the exclusion of hemin. In experiments using red cell ${ }^{50} \mathrm{Fe}$ uptakes as a measure of heme synthesis, control solutions of ferric chloride and iron dextran were prepared with the total elemental iron calculated to equal the amount contained in the administered hemin. The ferric chloride was dissolved in $1 \mathrm{~N} \mathrm{HCl}$ and diluted with $\mathrm{H}_{2} \mathrm{O}$ and $\mathrm{NaCl}$, and the $\mathrm{pH}$ was increased to 6.0 with $1 \mathrm{M}$ Tris. The dilutions of solutions were calculated to keep the $\mathrm{NaCl}$ concentration 0.15 to 0.20 mole per L. Solutions of iron dextran 4 were diluted with $0.9 \% \mathrm{NaCl}$. All solutions were prepared daily and were injected immediately after preparation. Injections were all into the tail vein on two successive days. On the third day the radioisotope was injected. Subsequent methods differed for the two radioisotopes.

Glycine-2 $-{ }^{14} \mathrm{C}$ uptake into hemin. Three $\mu \mathrm{c}$ of glycine${ }^{2}{ }^{14} \mathrm{C}$ was injected intraperitoneally, and 80 hours after injection $0.4 \mathrm{ml}$ of heparinized blood was obtained by

2 E. R. Squibb, New York, N. Y.

3 Nutritional Biochemical Co., St. Louis, Mo.

4 Lakeside Laboratory, Milwaukee, Wisc. intracardiac puncture. The blood was centrifuged at 800 $g$ for 15 minutes. The plasma was removed and the packed red cell pellet washed three times with cold phosphate-buffered $0.9 \% \mathrm{NaCl}, \mathrm{pH}$ 7.4. The red cells were then lysed with $3.0 \mathrm{ml}$ cold distilled water and $1.5 \mathrm{ml}$ Drabkin's solution and left overnight. The stromata were removed the following day by centrifuging at $15,000 \mathrm{~g}$ for 20 minutes in the cold. Cold $0.1 \mathrm{~N} \mathrm{HCl}$ was then added to bring the clear hemoglobin solution to approximately $\mathrm{pH} 2.0$. The $\mathrm{HCl}$ was added dropwise with constant mixing. The solution was then added to an equal volume of cold 2-butanone and immediately and vigorously mixed for 30 to 45 seconds (7). The volume of the heme (ketonic phase) was recorded and separated from the aqueous phase. The butanone was evaporated, and the crystals were isolated, washed twice with $50 \%$ acetic acid, twice with distilled $\mathrm{H}_{2} \mathrm{O}$, once with $95 \%$ ethyl alcohol, and once with ether. The purity of the crystals was tested by redissolving a small sample in 2-butanone. Approximately $1.5 \mu \mathrm{g}$ was spotted in two regions at the origin on Whatman 1 chromatography paper, and chromatograms were developed for 20 hours in a 2,6-lutidine, $\mathrm{H}_{2} \mathrm{O}, 1 \mathrm{~N} \mathrm{NH}_{4} \mathrm{OH}$ solvent $(10: 2.8: 4.1)$ ascending system (8). Controls of hemin chloride in butanone and aqueous alkaline hemin solutions were run simultaneously. The paper was divided and then sprayed with benzidine hydrochloride spray (9) except for the area above the second "test" spot, which after drying was isolated and cut into $1-\mathrm{cm}$ squares from origin to front. The squares were counted by adding to a $20-\mathrm{ml}$ glass counting vial ${ }^{5}$ containing $5 \mathrm{ml}$ of scintillator

5 Packard Instrument Co., La Grange, I11.

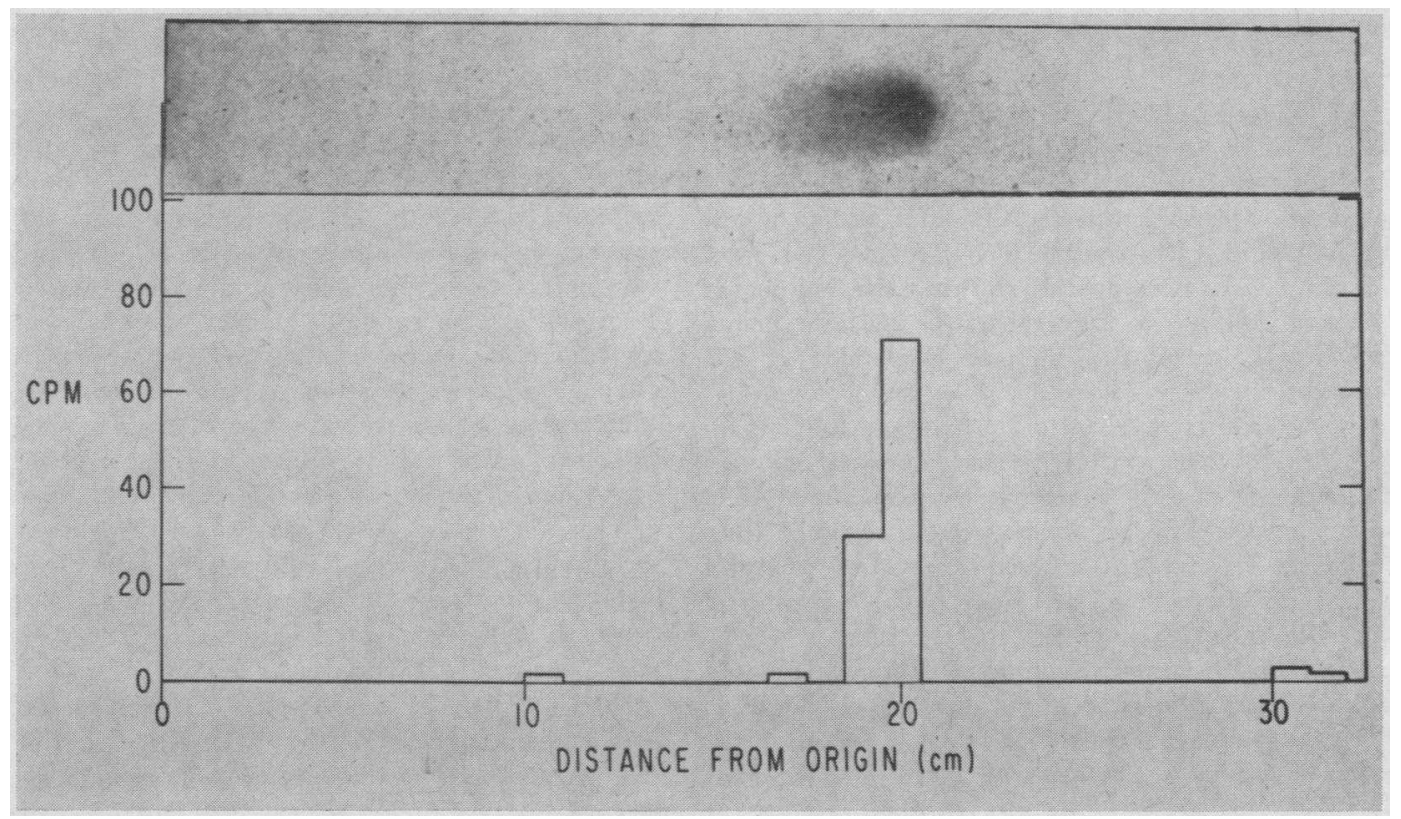

Fig. 1. Paper chromatograph of butanone extract of Red cells. Ascending 2,6-lutidine-water$\mathrm{NH}_{\mathbf{3}}$ system; heme $\mathrm{R}_{\mathbf{f}}, 0.62$. Upper part shows benzidine-stained chromatogram. Lower part is radioactivity of $1.0-\mathrm{cm}$ sections of a parallel run. 


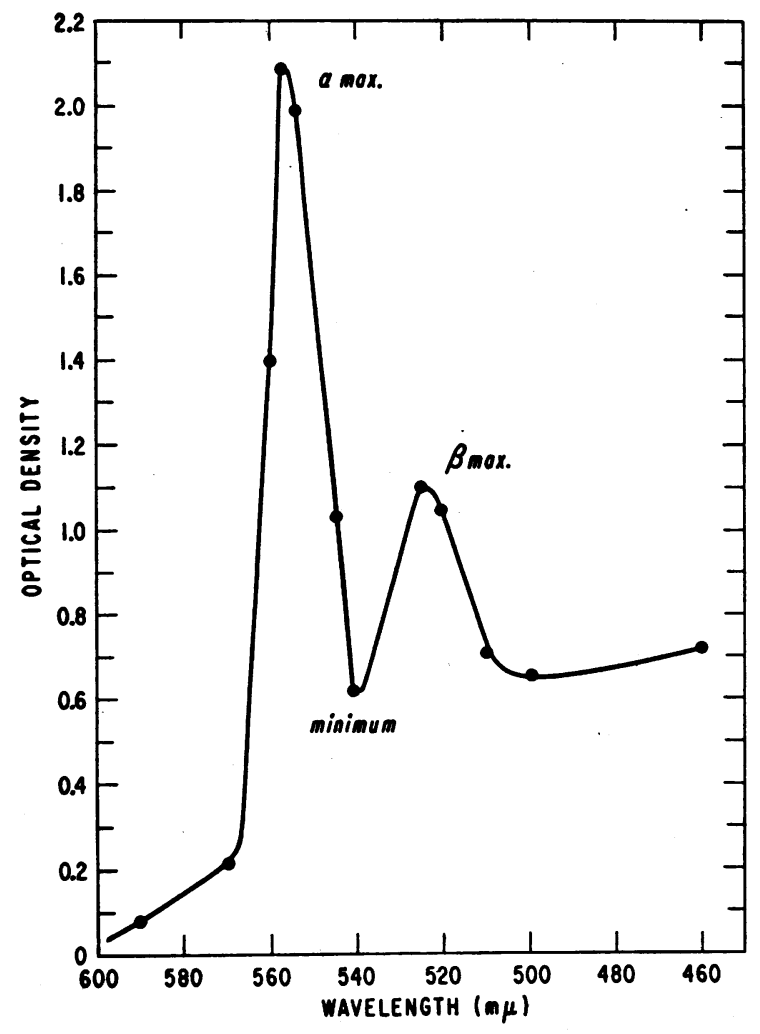

Fig. 2. Absorbancy SPECtrum of CRYSTALS isolated WITH BUTANONE. The monocyanide ferriprotoporphyrin crystals were dissolved in pyridine and reduced with $\mathrm{Na}_{2} \mathrm{~S}_{2} \mathrm{O}_{4}$. The spectrum of the derivative is identical to pyridine hemochromogen (pyridine ferroprotoporphyrin).

solution $^{6}$ (Figure 1). The remaining dry hemin crystals were dissolved in $1.0 \mathrm{ml}$ of pyridine, and a sample of the pyridine solution was used to determine the concentration of hemin spectrophotometrically after adding a few crystals of sodium hydrosulfite $\left(\mathrm{Na}_{2} \mathrm{~S}_{2} \mathrm{O}_{4}\right)$. The spectrum of the $\mathrm{CN}$-ferriprotoporphyrin after the addition of pyridine and $\mathrm{Na}_{2} \mathrm{~S}_{2} \mathrm{O}_{4}$ is identical to the pyridine hemochromogen and presumably reflects conversion of the $\mathrm{CN}$-ferriprotoporphyrin to the pyridine ferroprotoporphyrin (10). Readings were also taken at several wavelengths with particular attention to values at $557 \mathrm{m \mu}$, $526 \mathrm{~m} \mu$, and $541 \mathrm{~m} \mu$, the $\alpha$ maximum, $\beta$ maximum, and the minimum, respectively. The spectrum obtained from these analyses was used as another criterion of purity of the crystals (Figure 2). The values at the $\alpha$ maximum were used in calculations of the concentration.

A sample of the pyridine solution containing 5 to 15 $\mathrm{mg}$ of labeled hemin in $50 \mu \mathrm{l}$ of pyridine was dissolved in $1 \mathrm{ml} 1 \mathrm{M}$ Hyaminemethanol ${ }^{7}$ in glass counting vials. Sixteen $\mathrm{ml}$ scintillator solution was added, and the vials

6 Four $\mathrm{g}$ per $\mathrm{L}$ of 2,5-diphenyloxazole, $50 \mathrm{mg}$ per $\mathrm{L}$ of 1,4,-bis-2(5-phenyloxazoly1)-benzene, dissolved in toluene. ${ }^{7}$ Hydroxide of Hyamine, Packard Instrument Co. were counted in a liquid spectrometer. ${ }^{8}$ Correction for quenching was made with toluene- ${ }^{14} \mathrm{C}$ internal standard, radioactivity $4.37 \times 10^{5} \mathrm{dpm}$ per ml. ${ }^{9}$

Red cell ${ }^{50} \mathrm{Fe}$ uptake. After injections of hemin or control solutions on days 1 and $2,0.5 \mu \mathrm{c}$ of $\mathrm{Cl}_{3}{ }^{50} \mathrm{Fe}$ was injected into the tail vein on day 3. At the same time 0.5 $\mu \mathrm{c}$ was also injected into a flask (standard) and diluted to $50 \mathrm{ml}$ with distilled water. One-fourth of a milliliter of heparinized blood was obtained by intracardiac puncture at varying time intervals, and the radioactivity due to ${ }^{50} \mathrm{Fe}$ was determined in a well type scintillation gamma counter. ${ }^{10}$ A sample from the flask was also counted. The blood volume was calculated by multiplying total body weight by $6 \%$, and the total red cell radioactivity was determined by multiplying counts per minute per milliliter by blood volume. The per cent red cell ${ }^{50} \mathrm{Fe}$ uptake was calculated as per cent of the total counts injected (standard), and the mean value was determined from a group of six to ten animals.

Separate groups of mice received the same solutions but were sacrificed for determination of plasma iron ${ }^{11}$ immediately before the time ${ }^{\mathrm{s}} \mathrm{Fe}$ was to be injected (11).

Studies with protoporphyrin. Protoporphyrin IX was prepared by ether extraction of the porphyrin after overnight hydrolysis of the dimethyl ester with $7 \mathrm{~N} \mathrm{HCl}$ (12). The ether was allowed to evaporate, and the protoporphyrin crystals were prepared for injection as described above for hemin. The effect of protoporphyrin (100 $\mu$ moles per $\mathrm{kg}$ ) on the 48 -hour red cell ${ }^{\circ 0} \mathrm{Fe}$ uptake was studied in untreated mice and mice previously injected with hemin or with solvent control solutions. The solutions were given on 3 successive days in these experiments to avoid circulatory overload from the relatively large volume of solution.

Studies with $\delta$-aminolevulinic acid $(A L A) .12$ As in the studies with protoporphyrin, the effect of ALA on the 48 -hour red cell ${ }^{50} \mathrm{Fe}$ uptake was studied in mice previously treated with hemin and in untreated controls. The ALA was dissolved in distilled $\mathrm{H}_{2} \mathrm{O}$, and the $\mathrm{pH}$ was increased to 5.0 with $1 \mathrm{~N} \mathrm{NaOH}$. A total of 5.4 mmoles per $\mathrm{kg}$ was given intraperitoneally in one injection at varying intervals after heme (or solvent) injection and before ${ }^{50} \mathrm{Fe}$. As in most of the previous experiments, the hemin was given over a 2-day period.

Bone marrow morphology and reticulocyte counts. Reticulocyte counts were performed over a 6-day period in control mice and in mice previously injected with a total dose of $80 \mu$ moles per $\mathrm{kg}$ of hemin. The number of reticulocytes per 1,000 red cells was counted from a specimen of tail blood stained with new methylene blue, and the count was expressed as the per cent reticulocytes. Counts were performed on six different mice each

8 Tri-Carb model 3002, Packard Instrument Co.

9 Catalogue no. 6004062, Packard Instrument Co. 10 Model 8725,'Nuclear-Chicago Corp., Des Plaines, III.

11 Performed in the laboratory of Dr. Gerald Mendel, Dept. of Medicine, University of Chicago.

12 Lot 4011, A grade, Calbiochem, Los Angeles, Calif. 
day. The mean per cent of each group was obtained. After the blood had been obtained, the animals were sacrificed for bone marrow examination. Smears were made from marrow isolated from the femora and stained with Giemsa.

\section{Results}

Red cell ${ }^{59} \mathrm{Fe}$ uptakes. The total mouse heme synthesized per day may be calculated from the blood hemoglobin concentration, the per cent heme in hemoglobin, the total blood volume, and the red cell life-span. From data published on the mouse, the total heme synthesized in a 48-hour period is approximately 20 to $30 \mu$ moles per $\mathrm{kg}$ $(13,14)$. When this amount of heme was injected, there was no detectable effect on iron

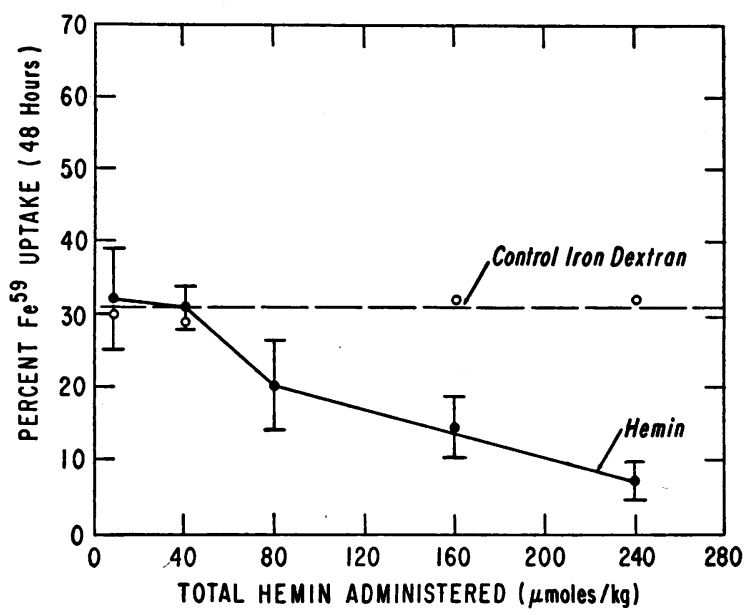

Fig. 3. Dose-RELATED INHIBITORY EFFeCT OF HEMIN ON 48-HOUR RED CELL ${ }^{50} \mathrm{FE}$ UPTAKE $\left(10^{-3} \mathrm{M}\right.$ CONCENTRATION). Hemin was administered over 2 days, the last injection approximately 18 hours before ${ }^{\circ 0} \mathrm{Fe}$ injection. Each point is the mean of eight animals. The lines bracketing each point are \pm standard deviation.

uptake, but with a total dose of $80 \mu$ moles per $\mathrm{kg}$ or approximately three times the heme synthesized over the 48-hour period of hemin administration, there was a $33 \%$ reduction when compared to control values $(t=4.6, \mathrm{p}<0.001)$ (15). Increasing the hemin to $240 \mu$ moles per $\mathrm{kg}$ and 300 $\mu$ moles per $\mathrm{kg}$ resulted in a $50 \%$ and $75 \%$ reduction, respectively (Figure 3 ). The inhibition was found as long as 4 days after the last injection of hemin (Figure 4). The value returned to control levels by the sixth day after the last hemin injection (not shown in the Figure).

Control solutions of ferric chloride and of iron dextran containing the same amount of elemental

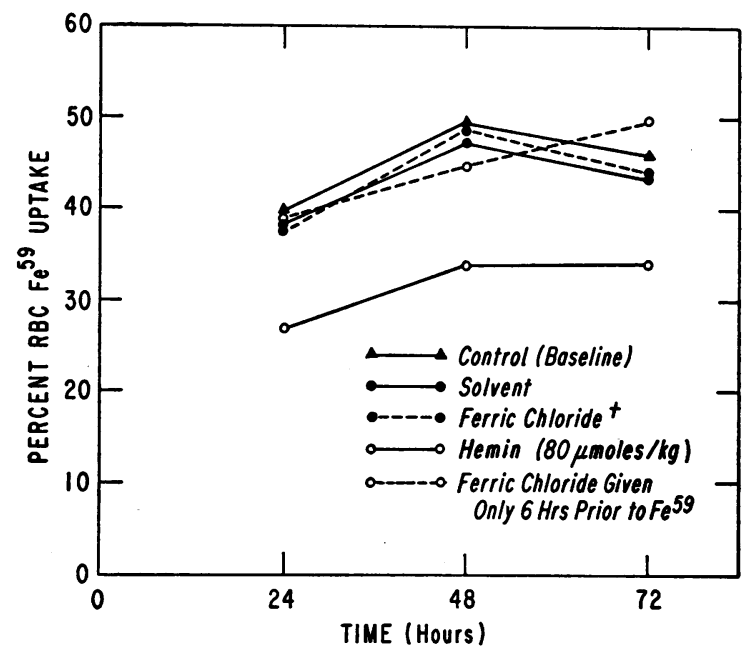

Fig. 4. EFFect OF HEMIN ON RED BLOOD CELL (RBC) ${ }^{60} \mathrm{FE}$ UPTAKES 24,48 , AND 72 HOURS AFTER ${ }^{50} \mathrm{FE}$. ${ }^{50} \mathrm{Fe}$ was given at 0 time. Test solutions (controls and hemin) were given 24 and 48 hours before ${ }^{\circ} \mathrm{Fe}$. "Base-line" controls received only ${ }^{\circ} \mathrm{Fe}$. Each point is the mean of between eight and ten animals.

iron as in the administered hemin had no effect on iron when given 1 and 2 days before ${ }^{59} \mathrm{Fe}$ injection, the same time the experimental animals had received hemin. The ferric chloride was also

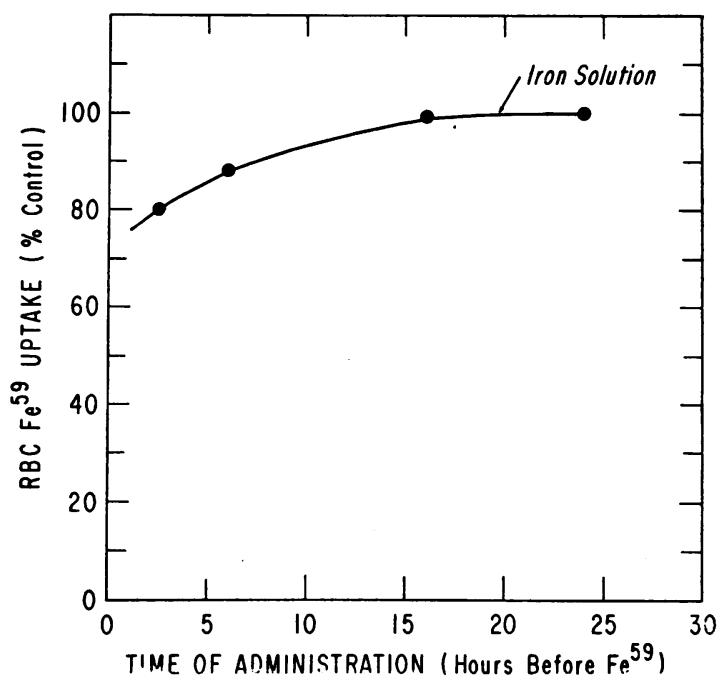

FIG. 5. EFFECT OF FERRIC CHLORIDE ON RED CELL ${ }^{\oplus} \mathrm{FE}$ UPTAKE. One hundred twenty $\mu \mathrm{g}$ was injected into each animal at variable periods before ${ }^{50} \mathrm{Fe}$ injection. Note lack of inhibition of red cell ${ }^{50} \mathrm{Fe}$ uptake except when ferric chloride was given only 3 or 6 hours before ${ }^{50} \mathrm{Fe}$. The degree of inhibition at these hours is not comparable to the effect due to heme. Each point is the mean of seven to nine animals. 


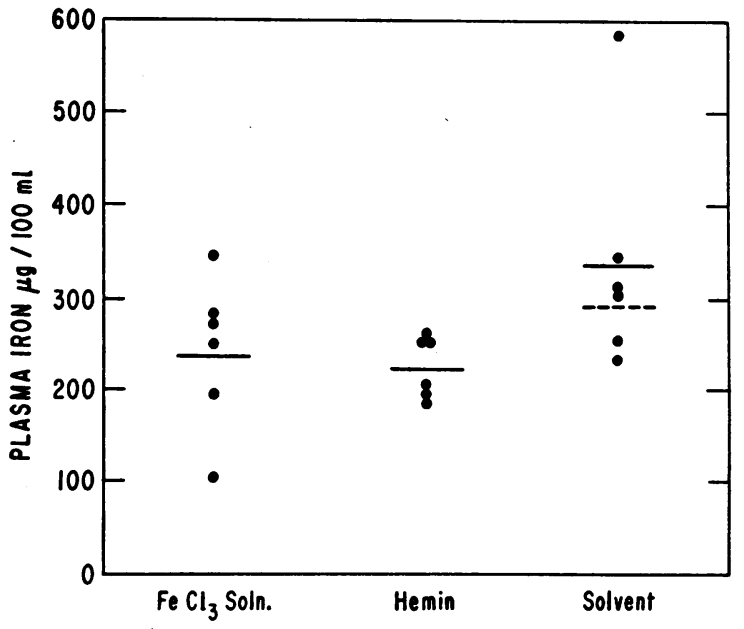

Fig. 6. Plasma iron values obtained immediately BEFORE INJECTION OF ${ }^{50} \mathrm{FE}$ IN CONTROLS AND IN MICE INJECTED WITH HEMIN. Bars (- $\longrightarrow$ ) represent mean values. Dashed bar $\left(---_{--}\right)$is the mean of the solvent control excluding the abnormally high value in one animal.

tested 16,6 , and 3 hours before ${ }^{59} \mathrm{Fe}$. There were $12 \%$ and $20 \%$ reductions in red cell ${ }^{59} \mathrm{Fe}$ uptakes in the 6-hour and 3-hour groups, respectively (Figure 5).

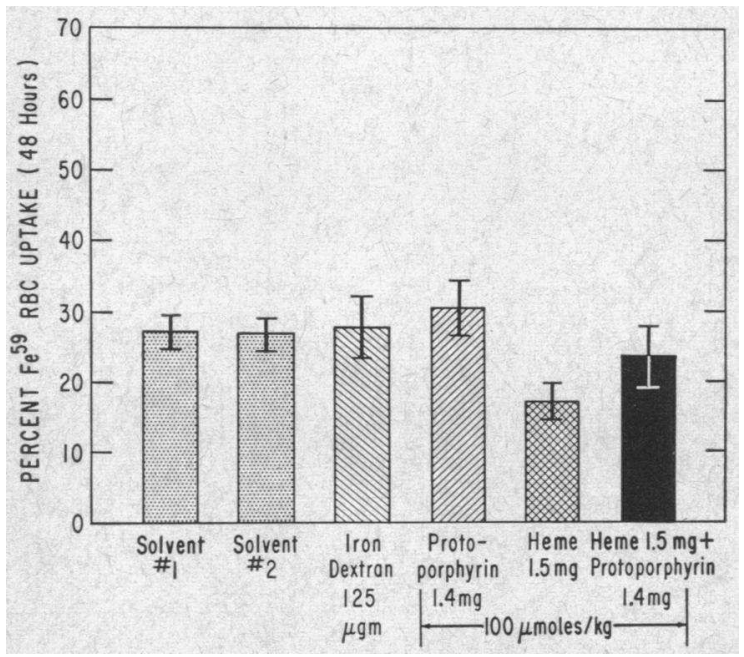

Fig. 7. EFFECT OF PROTOPORPHYRIN ON THE INHIBITORY EFFECT OF HEME. Solvent 1 is the heme solvent control. Solvent 2 is the control solution for the group receiving heme and protoporphyrin. Solutions were given in divided doses over 3 days. The addition of protoporphyrin to animals previously treated with heme has diminished the inhibitory effect of heme $(t=4.45, \mathrm{p}<0.001)$. Each bar is the mean of seven to ten mice, and the lines bracketing the bars are \pm standard deviation.
The plasma iron values in the experimental heme group were not higher than in the control groups. The mean values in the mice injected with hemin ( $90 \mu$ moles per $\mathrm{kg}$ over 2 days) were $221 \pm 29.5 \mu \mathrm{g}$ per $100 \mathrm{ml}$; in the solvent control group, $337 \pm 128.0 \mu \mathrm{g}$ per $100 \mathrm{ml}$; and in the control mice injected with ferric chloride, $238 \pm$ $43.9 \mu \mathrm{g}$ per $100 \mathrm{ml}$ (Figure 6). The data when considered together tend to exclude the possibility that the effect of hemin on red cell ${ }^{59} \mathrm{Fe}$ uptake is due to a dilution of the ${ }^{59} \mathrm{Fe}$ pool with unlabeled iron from the injected and subsequently catabolized hemin.

TABLE I

Effect of $\delta$-aminolevulinic acid $(A L A)^{*}$ and heme $\dagger$ on per cent red cell ${ }^{59} \mathrm{Fe}$ uptake at 48 hours

\begin{tabular}{|c|c|c|c|c|c|c|}
\hline \multirow[b]{2}{*}{ Group } & \multicolumn{5}{|c|}{ Substance injected (hours before ${ }^{50} \mathrm{Fe}$ ) } & \multirow{2}{*}{$\begin{array}{c}\text { Red cell } \\
\text { 59Fe } \\
\text { uptake }\end{array}$} \\
\hline & 40 & 20 & 8 & 3 & 0.5 & \\
\hline 1 & Solvent & Solvent & 0 & 0 & 0 & $34.2 \pm 5.1$ \\
\hline 2 & Heme & Heme & 0 & 0 & 0 & $18.9 \pm 3.2$ \\
\hline 3 & 0 & Heme & Heme & 0 & 0 & $17.7 \pm 2.9$ \\
\hline 4 & 0 & ALA & 0 & 0 & 0 & $25.4 \pm 7.6$ \\
\hline 5 & 0 & 0 & ALA & 0 & 0 & $31.2 \pm 4.1$ \\
\hline o & 0 & 0 & 0 & ALA & 0 & $32.6 \pm 5.5$ \\
\hline 7 & 0 & $\mathbf{0}$ & 0 & 0 & ALA & $34.9 \pm 4.1$ \\
\hline 8 & Heme & $\begin{array}{c}\text { Heme }+ \\
\text { ALA }\end{array}$ & 0 & 0 & 0 & $14.1 \pm 5.5$ \\
\hline 9 & Heme & Heme & ALA & 0 & 0 & $16.0 \pm 3.2$ \\
\hline 10 & Heme & Heme & 0 & ALA & 0 & $19.1 \pm 4.6$ \\
\hline 11 & Heme & Heme & 0 & 0 & ALA & $18.4 \pm 2.1$ \\
\hline
\end{tabular}

* Each injection, 5.4 mmoles per $\mathrm{kg}$.

$\dagger$ Each injection, $45 \mu$ moles per $\mathrm{kg}$.

$\ddagger$ Mean values of seven to ten animals \pm standard deviation.

Effect of protoporphyrin. When equimolar amounts of protoporphyrin were given to animals simultaneously treated with hemin, the inhibitory effect of hemin on red cell ${ }^{59} \mathrm{Fe}$ uptake was diminished by $64 \%(t=4.45, \mathrm{p}<0.001)(15)$. There was no effect from protoporphyrin alone (Figure 7). These results indicate that the effect of hemin is not through a dilution of the newly synthesized heme pool with unlabeled injected heme.

Effect of $A L A$. The experimental protocol and the results of studies with ALA are summarized in Table I. ALA was given at different periods before injection of ${ }^{59} \mathrm{Fe}$. Other groups received either solvent control, hemin alone, or hemin followed by ALA at varying intervals before ${ }^{59} \mathrm{Fe}$. When the last dose of hemin was given 8 to 20 hours before ${ }^{59} \mathrm{Fe}$, the reduction in red cell ${ }^{59} \mathrm{Fe}$ uptake at 48 hours was approximately $50 \%$. This correlated closely with the results with hemin in 
earlier experiments outlined above. The addition of ALA to animals previously treated with hemin did not alter the inhibitory effect of hemin on red cell iron uptake. When ALA was given 20 hours before ${ }^{59} \mathrm{Fe}$ to previously untreated mice, there was a decrease in red cell ${ }^{59} \mathrm{Fe}$ uptake to $74 \%$ of the control value. There was no detectable effect when the ALA was administered 30 minutes, 3 hours, or 8 hours before ${ }^{59} \mathrm{Fe}$ (Table I).

Incorporation of glycine $-2-{ }^{14} \mathrm{C}$ into hemin. The results of the counts of a typical paper chromatogram of the isolated hemin crystals are shown in Figure 1. More than $95 \%$ of the recovered radioactivity migrated with an $R_{\mathbf{f}}$ appropriate for hemin (0.62 to 0.63$)$ in every sample. A typical absorption spectrum of the reaction product of the cyanide ferriprotoporphyrin crystals with pyridine followed by reduction with $\mathrm{Na}_{2} \mathrm{~S}_{2} \mathrm{O}_{4}$ is shown in Figure 2. These spectra were identical to the pattern with recrystallized hemin converted to the pyridine hemochromogen. The ratio of the millimolar extinction coefficient of hemin prepared as described at the $\alpha$ maximum to the minimum (E millimolar $\alpha$ maximum/E millimolar $\alpha$ minimum) was approximately 3.4 . The value closely approximated the results reported by Paul, Theorell, and Åkeson (16). Results of the radioactivity of the paper chromatograms and the absorption spectrum of the isolated crystals outlined above demonstrate that the hemin crystals as prepared for counting radioactivity were relatively pure.

Figure 8 illustrates the effects of hemin administration on the utilization of glycine- $2-{ }^{14} \mathrm{C}$ for heme synthesis. The mean specific activity in the control group was $3,339 \pm 925 \mathrm{cpm}$ per $\mathrm{mg}$. The mean value in the mice injected with hemin was $1,273 \pm 172 \mathrm{cpm}$ per $\mathrm{mg}$. When total radioactivity of the samples was measured rather than specific activity, the mean value of animals injected with hemin was decreased to $50 \%$ of the controls.

Morphologic studies. There was no observable difference in the bone marrow morphology or in reticulocyte counts in the experimental and control groups (Figure 9).

Studies on the permeability of bone marrow cells to hemin $-{ }^{14} \mathrm{C}$ demonstrated that approximately $0.75 \%$ of the total labeled hemin per $1 \times$ $10^{6}$ nucleated cells entered the cells at a hemin- ${ }^{14} \mathrm{C}$

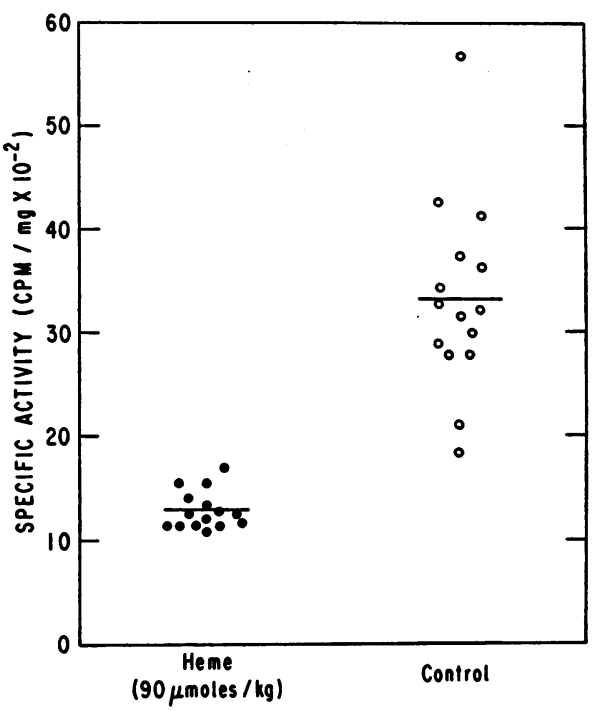

Fig. 8. INCORPORATION OF GLYCINE-2- ${ }^{14} \mathrm{C}$ INTO THE HEMIN OF ERYTHROCYTES.

concentration of $10^{-4}$ mole per $\mathrm{L}$. The details of these results will be reported in a separate communication.

\section{Discussion}

The results of the experiments demonstrating an inhibitory effect of hemin on red cell ${ }^{59} \mathrm{Fe}$ uptake may be interpreted as due to a dilution of the ${ }^{59} \mathrm{Fe}$ pool by iron released from the administered and subsequently catabolized hemin. The lack of significant inhibition by a comparable amount of iron given as the inorganic ferric chloride or as the or-

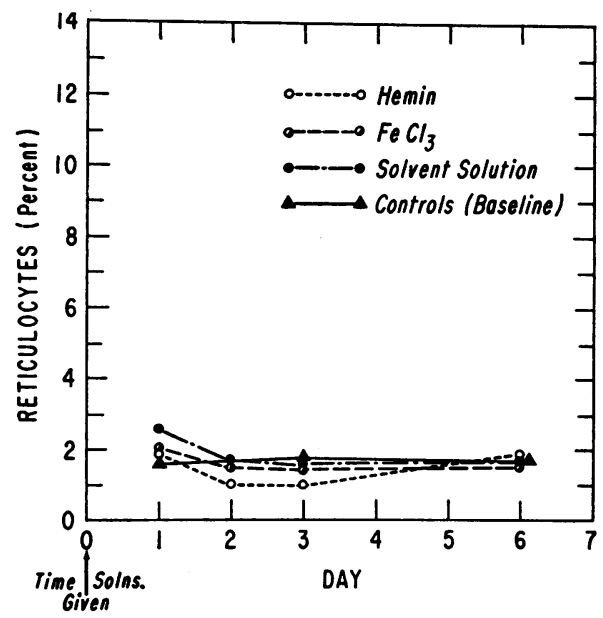

Fig. 9. Reticulocyte counts in control and heme GROUPS. Each point is the mean of six different mice. 
ganic complex iron dextran to control groups indicates that this is not the case. In addition, if there were significant dilution of the ${ }^{59} \mathrm{Fe}$ pool, an elevation in plasma iron would be expected. However, the plasma iron values in the mice injected with hemin were not significantly different from controls (Figure 6). Moreover, this explanation is not applicable to the results of the experiments with glycine-2-1 ${ }^{14} \mathrm{C}$.

An alternative explanation is that the effect of hemin is through a dilution of the newly synthesized heme pool with the administered hemin itself. This could result in competition between the injected hemin and labeled heme for globin. The injected hemin by competing with the newly synthesized heme for globin sites would decrease the per cent of labeled molecules of heme joined to globin and subsequently of the radioactivity detected in the peripheral blood. This argument is particularly applicable to the results with glycine-

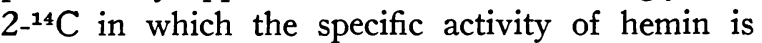
measured rather than total radioactivity. However, total hemin $-{ }^{14} \mathrm{C}$ radioactivity was also measured and was found to be significantly less in mice injected with hemin than in controls. Moreover, in experiments in which the effect of protoporphyrin on red cell ${ }^{59} \mathrm{Fe}$ uptake was studied, there was no effect on untreated mice. However, the administration of equimolar amounts of protoporphyrin to mice previously injected with hemin significantly diminished the inhibitory effect of hemin $(t=4.45, \mathrm{p}<0.001)$ (Figure 7$)$. These results cannot be explained by a dilution mechanism. Furthermore, the data of Ostrow, Jandl, and Schmid indicate that labeled heme is rapidly catabolized. Half of the radioactivity was recovered within 2 to 5 hours after infusion of hemoglobin $-{ }^{14} \mathrm{C}$ (17). In the experiments reported here, the radioactivity of peripheral red cells was not measured until at least 72 hours after hemin infusion with the exception of the one experiment in which the 24 -hour red cell ${ }^{59} \mathrm{Fe}$ uptake was measured.

It is possible that the inhibitory effect of hemin is a nonspecific noxious effect not limited to heme biosynthesis. The observations that heme produced minimal impairment in the utilization of ALA for heme synthesis $(2,4)$ and that heme stimulated globin synthesis (18) make this improbable.
In vivo studies of red cell ${ }^{59} \mathrm{Fe}$ uptake and glycine-2- ${ }^{14} \mathrm{C}$ incorporation into red cell hemin measure not only the rate of heme synthesis but may reflect in part the rate of reticulocyte formation. It is conceivable then that the inhibitory effect of hemin observed in this study was due to a decrease in the rate of reticulocyte entrance into the peripheral blood. The normal bone marrow morphology and reticulocyte counts indicate that this is not a significant effect. The results are in keeping with a direct inhibitory effect of hemin on the formation of heme. The possibility that this effect is due to a catabolic product of heme or of some heme complex such as methemalbumin has not been ruled out.

Although the exact site has not been identified, the experiments with protoporphyrin demonstrate that the inhibitory effect of hemin on heme synthesis occurs before the formation of protoporphyrin, and therefore not on the enzyme chelating iron and protoporphyrin (ferrochelatase) (Figure 7). Data published by others indicate that the site of inhibition is before the formation of ALA $(2,4)$. These sites include the formation of succinate, the activation of glycine and succinate, and the condensation of glycine with succinyl-coenzyme A catalyzed by ALAS. There is no information on the former possibilities, and from the available evidence it appears that the site of inhibition may be ALAS. This enzyme is the first and rate-limiting enzyme of heme biosynthesis (1), and a direct inhibitory effect of heme on ALAS has been demonstrated in the bacterium Rhodopseudomonas spheroides (2). It is of interest that heme may also be involved in the repression of ALAS formation. This has been recently demonstrated in a hepatic tryptophan pyrrolase system (19) and more directly by an inhibition of allylisopropylacetamide induction of ALAS activity in rats (20). The results reported in this communication do not distinguish between an effect mediated through repression of enzyme synthesis and one of direct enzyme inhibition.

If heme inhibits ALAS, it would be expected that the incorporation of glycine- $2-{ }^{14} \mathrm{C}$ into red cells would be inhibited by heme, and this inhibition was observed (Figure 8). On the other hand, the utilization of $\mathrm{ALA}-{ }^{14} \mathrm{C}$ for the synthesis of heme should not be affected by hemin. It would seem reasonable then to study the effect of hemin 
on the utilization of ALA- ${ }^{14} \mathrm{C}$ for heme synthesis. However, Schwartz has found that only 0.1 to $0.3 \%$ of the total injected $\mathrm{ALA}-{ }^{14} \mathrm{C}$ is incorporated into hemoglobin (21). This suggests a relative impermeability of erythroid elements to ALA. Similar findings have also been reported by others (22-24). Very low ALA- ${ }^{14} \mathrm{C}$ incorporation into heme would preclude in vivo studies of the effect of hemin on ALA-14 C incorporation into hemoglobin. On the other hand, it is possible to give pharmacologic amounts of unlabeled ALA in an attempt to overcome this relative impermeability. It would then be theoretically possible to bypass ALAS, the presumed site of hemin inhibition. If hemin inhibits ALAS, then the amount of free protoporphyrin available to chelate with iron would be diminished, and red cell iron uptakes would be comparatively reduced. The addition of ALA would increase protoporphyrin formation, and the red cell iron uptakes would be increased proportionate to the increase in hemoglobin synthesis. The results of such studies are shown in Table I. ALA did not diminish the inhibitory effect of hemin. This suggests that even with pharmacologic quantities ( 5.4 mmoles per $\mathrm{kg}$ ) of ALA there is insignificant entrance into erythroid precursors or that the site of hemin inhibition of heme synthesis is not ALAS.

The uptake of hemin $\left(10^{-4} \mathrm{M}\right)$ into a mixed population of a bone marrow cell suspension $\left(10^{\circ}\right.$ cells) was approximately $0.75 \%$ of the total hemin. Steady state conditions were achieved within 10 to 20 minutes of incubation, indicating a rapid influx of hemin. The rapidity with which influx of hemin equals efflux in an in vitro system is compatible with the in vitro demonstration of a rapid effect of hemin on heme synthesis (4).

Recent observations by Hammel and Bessman, Bruns and London, and Grayzel, Hörchner, and London indicate that heme stimulates globin synthesis $(6,18,25)$ apparently by stabilization of polyribosomes. Waxman and Rabinovitz reported that iron or hemin stabilizes polyribosomes (26), and Grayzel and associates clearly demonstrated that the preservation of polyribosomal integrity is due to hemin. Presumably, the effect of iron is due to chelation with protoporphyrin and the formation of heme (25). In light of this evidence, the hypothesis proposed by London of a feedback control mechanism by which heme inhibits its own formation and stimulates globin synthesis is appealing (27).

\section{Acknowledgments}

I am very grateful to $\mathrm{Dr}$. Stephen H. Robinson, Harvard Medical School; Dr. H. Marver and Dr. Gerald Mendel, University of Chicago School of Medicine; and Dr. Donald Tschudy, National Cancer Institute, National Institutes of Health, for their helpful suggestions.

\section{References}

1. Levere, R. D., and S. Granick. Control of hemoglobin synthesis in the cultured chick blastoderm by $\delta$-aminolevulinic acid synthetase: increase in the rate of hemoglobin formation with $\delta$-aminolevulinic acid. Proc. nat. Acad. Sci. (Wash.) 1965, 54, 134.

2. Burnham, B. F., and J. Lascelles. Control of porphyrin biosynthesis through a negative-feedback mechanism. Studies with preparations of $\delta$-aminolaevulate synthetase and $\delta$-aminolaevulate dehydratase from Rhodopseudomonas spheroides. Biochem. J. 1963, 87, 462.

3. Heady, R., N. Jacobs, and R. Deibel. Effect of haemin supplementation on porphyrin accumulation and catalase synthesis during anaerobic growth of Staphylococcus. Nature (Lond.) 1964, 203, 1285.

4. Karibian, D., and I. M. London. Control of heme synthesis by feedback inhibition. Biochem. biophys. Res. Commun. 1965, 18, 243.

5. Labbe, R., and G. Nishida. A new method of hemin isolation. Biochim. biophys. Acta (Amst.) 1957, 26, 437.

6. Hammel, C. L., and S. P. Bessman. Control of hemoglobin synthesis by oxygen tension in a cell-free system. Arch. Biochem. 1965, 110, 622.

7. Teale, F. W. J. Cleavage of the haem-protein link by acid methylethylketone. Biochim. biophys. Acta (Amst.) 1959, 35, 543.

8. Eriksen, L. Paper chromatography of porphyrin pigments. Scand. J. clin. Lab. Invest. 1953, 5, 155.

9. Connelly, J. L., M. Morrison, and E. Stotz. Hemins of beef heart muscle. J. biol. Chem. 1958, 233, 743.

10. Drabkin, D. L. Spectrophotometric studies. IX. The reaction of cyanide with nitrogenous derivatives of ferriprotoporphyrin. J. biol. Chem. 1942, 142, 855.

11. Bothwell, T. H., and B. Mallett. The determination of iron in plasma or serum. Biochem. J. 1955, 59, 599.

12. Falk, J. Porphyrins and Metalloporphyrins. Amsterdam, Elsevier, 1964, p. 126.

13. Wintrobe, M. M. Variations in the size and hemoglobin content of erythrocytes in the blood of various vertebrates. Folia haemat. (Lpz.) 1934, 51, 32.

14. Von Ehrenstein, G. The life span of the erythrocytes of normal and of tumour-bearing mice as deter- 
mined by glycine-2- ${ }^{14} \mathrm{C}$. Acta physiol. scand. 1958, 44, 80.

15. Croxton, F. E. Elementary Statistics with Applications in Medicine and the Biological Sciences, 1st ed. New York, Dover, 1959, pp. 221, 312.

16. Paul, K. G., H. Theorell, and A. Åkeson. The molar light absorption of pyridine ferroprotoporphyrin (pyridine haemochromogen). Acta chem. scand. $1953,7,1284$.

17. Ostrow, J. D., J. H. Jandl, and R. Schmid. The formation of bilirubin from hemoglobin in vitro. $\mathrm{J}$. clin. Invest. 1962, 41, 1628.

18. Bruns, G. P., and I. M. London. The effect of hemin on the synthesis of globin. Biochem. biophys. Res. Commun. 1965, 18, 236.

19. Marver, H. S., D. Tschudy, M. G. Perlroth, and A. Collins. The regulation of heme biosynthesis. Science 1966, in press.

20. Waxman, A., and D. Tschudy. Personal communication.

21. Schwartz, S. Personal communication.
22. Shemin, D. Ciba Foundation Symposium of Porphyrin Biosynthesis and Metabolism. London, J. \& A. Churchill, 1955, pp. 4, 19.

23. Berlin, N. I., A. Neuberger, and J. J. Scott. The metabolism of $\delta$-aminolevulinic acid. I. Normal pathways, studied with the aid of ${ }^{15} \mathrm{~N}$. Biochem. J. 1956, 64, 80.

24. Scott, J. J. Ciba Foundation Symposium on Porphyrin Biosynthesis and Metabolism. London, J. \& A. Churchill, 1955, p. 53.

25. Grayzel, A. I., P. Hörchner, and I. M. London. The stimulation of globin synthesis by heme. Proc. nat. Acad. Sci. (Wash.) 1966, 55, 650.

26. Waxman, H. S., and M. Rabinovitz. Iron supplementation in vitro and the state of aggregation and function of reticulocyte ribosomes in hemoglobin synthesis. Biochem. biophys. Res. Commun. $1965,19,538$.

27. London, I. M., G. P. Bruns, and D. Karibian. The regulation of hemoglobin synthesis and the pathogenesis of some hypochromic anemias. Medicine (Baltimore) 1964, 43, 789. 